http://jmscr.igmpublication.org/home/ ISSN (e)-2347-176x ISSN (p) 2455-0450 crossref DOI: https://dx.doi.org/10.18535/jmscr/v8i2.45

\author{
Dournal Of Medical Science And Clinical Research \\ IGM Publication \\ An Official Publication of IGM Publication
}

\title{
Serum Uric Level as a Marker of Myocardial Infarction
}

\author{
Authors \\ Dr Richa Giri ${ }^{1}$, Dr Mohit Sachan ${ }^{2}$, Dr Gaurav Chaudhary ${ }^{3}$, Dr Shivendra Verma ${ }^{4}$ \\ ${ }^{1}$ Director, Professor and Head of Department of KPS Institute of General Medicine GSVM Kanpur \\ ${ }^{2}$ Associate Professor (DM Cardiology) in KPS Institute of General Medicine GSVM Kanpur \\ ${ }^{3}$ Resident in KPS Institute of General Medicine GSVM Kanpur \\ ${ }^{4}$ Associate Professor (DM Endocrinology) in KPS Institute of General Medicine GSVM Kanpur
}

\begin{abstract}
Background: Serum uric acid (SUA) is linked to various diseases but its association with the myocardial infarction(MI) has led physician to find whether it can be used in diagnosing MI ,this study was to assess and find clinical value of SUA in MI.

Methods: This prospective study was studied in patients of MI willing to give informed consents and was diagnosed on the basis clinical history electrocardiography, troponin I level from august 2017 to September 2019.The relationship between troponin I level and SUA were analysed. All data were analysed using SPSS version 17 software for independent student t test and Pearson's correlation coefficient analysis.

Results: The mean age of the patient who took part in the study was $57.31 \pm 12.016$ years and for the control group was $48.99 \pm 13.39$ years

For Myocardial group mean value of serum uric acid $(\mathrm{mg} / \mathrm{dl})$ is $6.6 \pm 1.6$ vs.3.9 \pm 0.31 in control group $(p$ value is $<0.001$ )

The mean serum uric acid in NSTEMI $(6.77 \pm 1.70 \mathrm{mg} / \mathrm{dl})$ was higher than STEMI $(6.52 \pm 1.57 \mathrm{mg} / \mathrm{dl})$ but difference was not statistically significant $(p=0.628)$.

Conclusion: SUA is significantly raised in MI patients and is positively correlated with Troponin level.
\end{abstract}

\section{Introduction}

Coronary artery disease is worldwide epidemic. Prevalence has risen over past decade and responsible for $20 \%$ death in India only due to higher prevalence of risk factor related to change in life style of the people ${ }^{1}$. Limitation of available resources to diagnose myocardial infarction forces authorities to search for other diagnostic criteria that are easily available and are cost effective.

There is some link found between the serum uric acid and cardiovascular events, researchers have found that high serum uric acid level predisposes myocardial infarction $^{2}$
Tissue hypoperfusion due to myocardial infarction triggers xanthine oxidase activation and oxidative stress which leads to rise in uric acid level and lead to heart failure and vicious cycle of hypoperfusion began.

We took this study to further supports the evidence is there is any correlation between serum uric acid level and myocardial infarction.

\section{Material and Methods Source of Data}

Patients of acute myocardial infarction and willing to give consent, reaching medicine department of 
LLR and associated hospital GSVM medical college, Kanpur from August 2017 to September 2019.

\section{Methods of collection of data}

Study Design: Prospective single-centre observational study

Place of Study: The present analysis was a conducted at the GSVM MEDICAL COLLEGE KANPUR India.

Study Period: Between August 2017 and SEPTEMBER 2019.

Inclusion Criteria: Patients $>18$ years of age

With STEMI or non-ST segment elevation MI (NSTEMI) on the basis of

History

Clinical examination

Electrocardiographically changes

Troponin I

\section{Exclusion Criteria}

Condition known to raise SUA level (e.g., chronic kidney disease, gout, haematological malignancy, hypothyroidism, hyperparathyroidism) were excluded. Drugs that raise SUA (e.g., salicylates [>2 g/day], ethambutol, amiloride, bumetanide, chlorthalidone, cisplatin, cyclophosphamide, cyclosporine, ethacrynic acid, thiazide diuretics, furosemide, indapamide, isotretinoin, ketoconazole, levodopa, metolazone, pentamidine, phencyclidine, pyrazinamide, theophylline, vincristine or vitamin $\mathrm{C}$ were also excluded, as were chronic alcoholics.

\section{Statistical Analysis}

The data was collected and entered in MS Excel and a master chart was made. The data was analysed using appropriate statistical tools i.e. SPSS ( $23^{\text {rd }}$ version) like percentage, mean, SD by using chi square test and test and results were drawn accordingly.

\section{Observation}

In our study we studied 49 patient of myocardial infarction and 48 control patient which are age and sex matched $(\mathrm{p}>0.5)$. Myocardial patient were divided into ST elevation and Non ST elevation.

ST elevation was further divided into, Anterior wall myocardial infarction (AWMI), Inferior wall myocardial infarction.

Table 1: Descriptive Statistic For Age

\begin{tabular}{|l|c|c|c|c|c|}
\hline AGE & $\mathrm{N}$ & Minimum & Maximum & Mean & Std. Deviation \\
\hline CASE & 49 & 35 & 91 & 57.31 & 12.016 \\
Control & 48 & 28 & 80 & 52.56 & 13.27 \\
\hline
\end{tabular}

Independent $\mathrm{t}$ test was applied on age of $\mathrm{MI}$ patients and control, the $\mathrm{p}$ value equals to 0.07 which was greater than 0.05 indicating there was no significant difference in age of two groups.

The mean age of the patient who took part in the study was $57.31 \pm 12.016$ years and for the control group was $48.99 \pm 13.39$ years.

Table 2: Distribution of Gender

\begin{tabular}{|l|c|c|}
\hline \multicolumn{1}{|c|}{ Gender } & Male & Female \\
\hline Total patient $(\mathrm{n}=49)$ & 33 & 16 \\
\hline Percentage & 67.3 & 32.7 \\
\hline
\end{tabular}

Table 3: Mean Serum Uric Acid Level in Case and in Control

\begin{tabular}{|l|c|c|c|}
\hline & Myocardial infarction & control & P value \\
\hline Serum uric acid $(\mathrm{mg} / \mathrm{dl})$ & $6.6 \pm 1.6$ & $3.9 \pm 0.31$ & $<0.001$ \\
\hline
\end{tabular}


For Myocardial group mean value of serum uric acid $(\mathrm{mg} / \mathrm{dl})$ is $6.6 \pm 1.6$ vs $3.9 \pm 0.31$ in control group .The Independent student $\mathrm{t}$ - test is applied, $\mathrm{p}$ value is $<0.001$ indicating that serum uric acid is significantly higher in myocardial infarction patient.

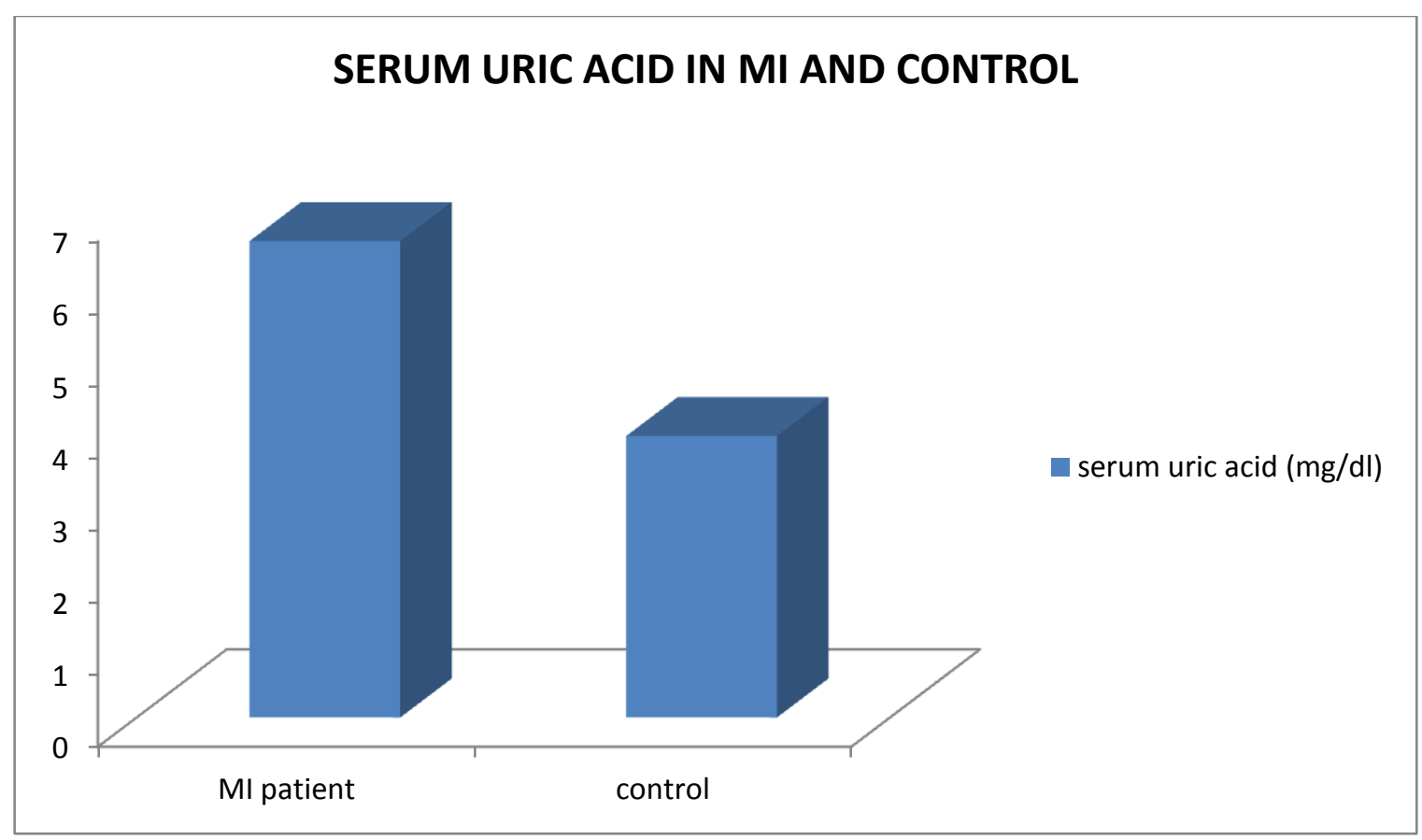

Fig 1: Mean serum uric acid distribution in case and control

Table 4: Pearson Correlation between Sua and Troponin I

\begin{tabular}{|l|c|c|c|}
\hline & N & $\begin{array}{c}\text { Pearson' correlation } \\
\text { coefficient }\end{array}$ & $\begin{array}{c}\text { P } \\
\text { value }\end{array}$ \\
\hline $\begin{array}{l}\text { serum uric acid } \\
\text { and serum } \\
\text { troponin I }\end{array}$ & 49 & 0.692 & $<0.001$ \\
\hline
\end{tabular}

$\mathrm{P}$ value comes out to be $<0.001$ so there is significant correlation between serum uric acid level and troponin I levels.

The mean serum uric acid in NSTEMI was $6.77 \pm$ $1.70 \mathrm{mg} / \mathrm{dl}$ and STEMI $6.52 \pm 1.57 \mathrm{mg} / \mathrm{dl}$ but there was no significant difference $(\mathrm{p}=0.628)$. The mean serum uric acid was $6.71 \pm 1.52 \mathrm{mg} / \mathrm{dl}$ in patients who had anterior wall myocardial infarction, $6.77 \pm 1.64 \mathrm{mg} / \mathrm{dl}$ in patients of inferior wall myocardial infarction but the difference was not statistically significant $(p=0.429)$

\section{Discussion}

This study was conducted with aim to study serum uric acid as a prognostic marker of acute myocardial infarction (AMI) 85 patients were taken for the study of which 13 were refused to give consent 23 was excluded from the study on the basis of exclusion criteria, remaining 49 patient of acute myocardial infarction were selected for study purpose of whom 33 are male and 16 are female. Forty eight age and gender matched control were also evaluated for their base line SUA and there was no significant difference was there between them. There was male preponderance in the study and also shows high preponderance of acute myocardial infarction in male as compared to female which was concordant to the previous study which also a higher male preponderance as by Dr. Srikant et al (2017) and Vladimir Trkulja et al (2011)

Maximum numbers of patient of AMI were in the age group $41-60$ years.

The mean age of the patient who took part in the study was $57.31 \pm 12.016$ years for AMI and for the control group was52.56 \pm 13.27 . Burki.l et al (2013) had taken mean age of $50.0 \pm 12.4$ in case group and $51.8 \pm 10.1$ in their control group

STEMI was commoner than NSTEMI and among those who have STEMI majority has AWMI in 
comparison to IWMI was similar in result as shown by Dr. Srikant (2017) et al.

The mean serum uric acid level was significantly higher in acute myocardial group in comparison to control group on the day of admission which was similar with regards to past study as by Padma et al (2017), R. K. Chowdhary et al (2016)

There is positive correlation between serum uric acid level and troponin I and it is statistically significant $(<0.05)$

Mean serum uric acid level was higher in NSTEMI group in comparison to STEMI group which was similar to previous study as shown by Prasanta k. b et al (2016)

In STEMI group mean serum uric acid was higher in IWMI group in comparison to AWMI group which was not significant.

\section{Conclusion}

In our study we concluded that serum uric acid is significantly higher with acute MI in comparison to normal healthy group, and higher serum uric acid level is significantly correlated with higher troponin I

\section{Bibliography}

1. Abhishek goyal etal(2017)changes in the prevalence and social distribution of cardiovascular disease and risk factors in India in volume 9,eo10947.

2. Mehrpooya M et al (2017). Study of Serum Uric Acid Levels in Myocardial Infarction and Its Association With Killip Class Acta Med Iran. 2017 Feb;55(2):97102.

3. Suyoung Jang et al 2014. CLINICAL IMPACT OF SERUM URIC ACID IN PATIENTS WITH ACUTE MYOCARDIAL INFARCTION Journal of the American College of Cardiology Volume 63, Issue 12 Supplement, April 2014DOI: 10.1016/S0735-1097(14)602394

4. Baker JF et al (2005) CLINICAL IMPACT OF SERUM URIC ACID IN

\section{PATIENTS}

WITH

ACUTE

MYOCARDIAL INFARCTION Am J Med. 2005 Aug;118(8):816-26.

5. Padma V et al.( 2017 ) Serum uric acid levels in acute myocardial infarction Int $\mathbf{J}$ Adv Med. 2017 Aug; 4(4):1010-1013

6. Nadkar MY ${ }^{1}$, Jain VI. Serum uric acid in acute myocardial infarction. (2008)J Assoc Physicians India. 2008 Oct;56:759-62

7. Michiel J. Bos, et al (2006) Uric Acid Is a Risk Factor for Myocardial Infarction and Stroke The Rotterdam Study (Stroke. 2006;37:1503-1507.)

8. Ravella Keerthika Chowdary et al (2016) Prognostic value of serum uric acid level in patients with acute myocardial infarction Curr Res Cardiol 2016;3(3):6366.

9. Burki, L. et al (2013) Annals of King Edward Medical University (Print); ISSN 2079-7192; v. 19(3); p. 243-249

10. Suresh Kumar Behera, Akshaya Kumar Samal (2018) Study of serum uric acid level as a prognostic marker in acute ST elevation myocardial infarction patients DOI: http://dx.doi.org/10.18203/23493933.ijam 20182108

11. Kaushik Biswas et al(2016) A study on prognostic significance of serum uric acid in acute myocardial infarction in a tertiary care institute DOI: http:// dx.doi.org/10.18203/23206012.ijrms20163329

12. Sunao Kojima et al (2005) Prognostic Usefulness of Serum Uric Acid After Acute Myocardial Infarction (The Japanese Acute Coronary Syndrome Study) DOI: https:// doi.org/10.1016/j.amjcard.2005.04.007

13. Dr.Srikanth (2017) Crp And Uric Acid Levels As a prognostic Markers In Acute Myocardial Infarction IOSR Journal of Dental and Medical Sciences (IOSRJDMS) e-ISSN: 2279-0853, p-ISSN: 22790861.Volume 16, Issue 3 Ver. II 
(March.2017),

PP $14-20$

www.iosrjournals.org DOI: 10.9790/0853-

1603021420www.iosrjournals.org 14| Page

14. Vladimir Trkulja (2011) On-admission serum uric acid predicts outcomes after acute myocardial infarction: systematic review and meta-analysis of prognostic studies CLINICAL SCIENCE doi: 10.3325/cmj.2012.53. 162 www.cmj.hr 